\title{
Ethnodiagnostic skills of the Digo community for malaria: a lead to traditional bioprospecting
}

\section{Joseph Mwanzia Nguta ${ }^{*}$, James M. Mbaria ${ }^{1}$, Peter K. Gathumbi ${ }^{2}$, Daniel Gakuya ${ }^{3}$, John David Kabasa ${ }^{4,5}$ and Stephen Gitahi Kiama ${ }^{6}$}

1 Department of Public Health, Pharmacology and Toxicology, University of Nairobi, Nairobi, Kenya

2 Department of Veterinary Pathology, Microbiology and Parasitology, University of Nairobi, Nairobi, Kenya

${ }^{3}$ Department of Clinical Studies, University of Nairobi, Nairobi, Kenya

${ }^{4}$ Department of Physiology, Makerere University, Kampala, Uganda

${ }^{5}$ Department of Pharmacology, Makerere University, Kampala, Uganda

${ }^{6}$ Department of Veterinary Anatomy and Physiology, University of Nairobi, Nairobi, Kenya

\section{Edited by:}

Alvaro Viljoen, Tshwane University of Technology, South Africa

\section{Reviewed by:}

Maria do Céu Gonçalves da Costa, Laboratório Nacional de Energia e Geologia, Portugal

Alex Asase, University of Ghana, Ghana

*Correspondence:

Joseph Mwanzia Nguta, Department of Public Health, Pharmacology and Toxicology, University of Nairobi, Box 29053-00625, Nairobi.

e-mail: joseph.nguta@uonbi.ac.ke
Malaria is a major public health problem that is presently complicated by the development of resistance by Plasmodium falciparum to the mainstay drugs. Thus, new drugs with unique structures and mechanism of action are required to treat drug-resistant strains of malaria. Historically, compounds containing a novel structure from natural origin represent a major source for the discovery and development of new drugs for several diseases. This paper presents ethnophytotherapeutic remedies, ethnodiagnostic skills, and related traditional knowledge utilized by the Digo community of the Kenyan Coast to diagnose malaria as a lead to traditional bioprospecting. The current study was carried out in three Digo villages of Diani sub-location between May 2009 and December 2009. Data was collected using semi-structured interviews, and open and close-ended questionnaires. A total of 60 respondents (34 men and 26 women) provided the targeted information. The results show that the indigenous knowledge of Digo community on malaria encompasses not only the symptoms of malaria but also the factors that are responsible for causing malaria, attributes favoring the breeding of mosquitoes and practices employed to guard against mosquito bites or to protect households against malaria. This knowledge is closely in harmony with scientific approaches to the treatment and control of the disease. The Digo community uses 60 medicinal plants distributed in 52 genera and 27 families to treat malaria. The most frequently mentioned symptoms were fever, joint pains, and vomiting while the most frequently mentioned practices employed to guard against mosquito bites and/or to protect households against malaria was burning of herbal plants such as Ocimum suave and ingestion of herbal decoctions and concoctions. The Digo community has abundant ethnodiagnostic skills for malaria which forms the basis of their traditional bioprospecting techniques.

Keywords: malaria, antimalarials, ethnopharmacology, ethnodiagnostic skills, Digo community, bioprospecting

\section{INTRODUCTION}

Malaria kills 1-2 million people each year globally and 300-500 million new clinical cases of the disease are reported annually (Snow et al., 2005). Malaria constitutes one of the biggest health problems in tropical Africa and is slowly spreading to hitherto nonmalaria areas (Trape, 2002). The emergence of resistant parasites, changes in climatic conditions over a large part of Africa, changes in land use and population migration (Foster, 1991; Ridley, 1997) are extending the areas of malaria transmission, which requires innovative strategies for malaria and the mosquito vector control. It is estimated that the malaria incidence range between 350 and 500 million cases globally, with $90 \%$ of these being in tropical Africa (World Health Organization, 2005). In Kenya, more than $90 \%$ of malaria is caused by Plasmodium falciparum (Khaemba et al., 1994) transmitted by Anopheles gambiae which is the most widespread in Africa and difficult to control. Each year, there are over 8.2 million malaria infections in Kenya (Jean-Marie, 2002) mostly due to inadequate medical care, unavailability of insecticide treated nets and increased resistance of the parasites to drugs. The disease accounts for $30 \%$ of all the outpatient cases and $19 \%$ of all admissions, $5.1 \%$ of whom die, and 72 children below the age of 5 years die daily (World Health Organization, 1996; Mouchet, 1999; Director of Medical Services, 2006). The disease is endemic in the lowlands, particularly the coastal strip where transmission is sufficiently intense (Muthaura et al., 2011). Both incidence and prevalence of infection reach more than $90 \%$ of the population within 10-12 weeks after the beginning of the rainy season (Hoffman et al., 1996).

Human malaria transmitted by female Anopheles mosquitoes is caused by four species of Plasmodium, which are, P. falciparum, P. vivax, P. ovale, and P. malariae. Most cases of malaria and deaths are caused by $P$. falciparum. The development of resistance 
to mainstay drugs like chloroquine and controlled use of new artemisinin analogs have created an urgent need to discover new antimalarial agents. The life cycle, immunological defense mechanisms, and clinical development of malaria in humans are complex processes (Kumar et al., 2002) and successful chemotherapeutic intervention is essential in control of the disease. Nature remains an ever evolving source for compounds of medicinal importance. The use of medicinal plants for the treatment of parasitic diseases is well known and documented since ancient times. For example, use of Cinchona succirubra (Rubiaceae) for the treatment of malaria infection is known for centuries. Several compounds isolated from nature also form a rich source of diverse structures for optimization to obtain improved therapeutics. A number of natural products having antimalarial activities have been documented (Sharma and Sharma, 2001).

The Digo community is one of the nine deeply traditional ethnic groups that form the Mijikenda community of the Kenyan coast. They inhabit a malaria endemic zone and have developed impressive traditional procedures to diagnose, prevent, and treat malaria. In addition, they have a well established ethnomedical practice to cure and control the disease. This knowledge acquired through history taking, observation, and palpation of sick members of the society has evolved into an ethnodiagnostic procedure, which is a major contributor to the Digo traditional bioprospecting skills. Ethnopharmacological studies on antimalarial herbal remedies in the Digo inhabited regions of Kenya have been conducted (Nguta et al., 2010a). Studies utilizing specialized knowledge to document plants traditionally used by the Digo community to treat malaria have also been accomplished (Muthaura et al., 2007). These activities are focused on the discovering of new antimalarial drugs of plant origin to combat antimalarial drug resistance. In the neighboring country of Uganda, herbal medicines used in the treatment of malaria as well as the existing knowledge, attitudes, and practices related to malaria recognition, control, and treatment in Budiope county have also been documented (Tabuti, 2008). In Tanzania, medicinal plants have been screened against malarial causal agent, $P$. falciparum (Maregesi et al., 2010). The Digo people occupy a high incidence area for malaria at the Kenyan coast (Director of Medical Services, 2006) and have a great variety of unique traditional knowledge about malaria recognition and they widely use natural resources in treatment of the disease. However, the ethnodiagnostic skills utilized by the Digo community to treat malaria have not been documented.

The main objectives of the current study were to explore the traditional knowledge of malaria diagnosis and ethnophytotherapeutic practices in three Digo villages of Mwamambi A, Mwamambi B, and Mwaroni. The documented information will be the basis of: (1) selection of antimalarial plant species for pharmacological, toxicological, and phytochemical studies (2) collection and preservation of the valuable popular knowledge concerning antimalarial plant use (3) addition of information to the valuation of biodiversity and to forward suggestions for its sustainable use and conservation (4) establishing comparisons with other territories sharing similar characteristics (5) selection of plants for isolation of new and novel molecules for development as antimalarials and (6) setting up health policies in regard to prevention and treatment of malaria. The paper also addresses the questions: (1) which ethnodiagnostic skills do the Digo community utilize as a lead to traditional bioprospecting? (2) which plants does the Digo community use to treat malaria?

\section{MATERIALS AND METHODS STUDY AREA}

In South Coast, the study area centered around $04^{\circ} 28^{\prime} 59.2^{\prime \prime} \mathrm{S}$ latitude and $039^{\circ} 33^{\prime} 36.2^{\prime \prime}$ E longitude in and around Mwaroni, Mwamambi A, and Mwamambi B villages of Ngombato sub-location, Diani location found in Diani division, Msambweni district in Coast province of Kenya. The area is hot and humid all year round with annual mean temperatures ranging between 23 and $34^{\circ} \mathrm{C}$ and the average relative humidity ranging between 60 and $80 \%$. The soils are made of sandstone and grit and are fairly fertile for cultivation. The area has monsoon climate, hot and dry from January to April while June to August is the coolest period. Rainfall comes in two seasons with short rains from October to December and long rains from March/April to July. The total precipitation varies from 900 to $1500 \mathrm{~mm}$ per annum along the coastal belt to 500$600 \mathrm{~mm}$ in the hinterland, which comprise $92 \%$ of the land whose agricultural potential is low (Nguta et al., 2010a). The study area is mainly inhabited by the Digo community, a Bantu tribe with a population of 225,000 (1999 Kenya National Population Census), $90 \%$ of who are Muslims and are concentrated on the southern coastal strip of Kenya between Mombasa and the border of Tanzania (Nguta et al., 2010a). The traditional way of life and customary beliefs of the Digo community are quite intact and the acceptability of antimalarial medicinal plants as claimed effective remedies is quite high among the population of this area. The Kaya forests in Digo area are the social-cultural focal points of the community. They are preserved as sacred ceremonial sites, and cultural taboos prohibit the cutting of trees except for select purposes, thus biodiversity is sustained. More than half of Kenyan's rare plants have been identified within the Kaya forest patches (Muthaura et al., 2007). The traditional medicinal knowledge from the resources of these forests requires documentation for the benefit of the current and future generations.

The medicinal knowledge of the Digo community is considered communal. The Digo community have good knowledge on the use of medicinal plants and this knowledge was bequeathed to them by their fathers, albeit orally, from generation to generation (Muthaura et al., 2007). The community is rural and depends on crop agriculture as its major source of livelihood. $P$. falciparum is the commonest species in the study area and is associated with significant morbidity and mortality of children aged 5 years and below and pregnant women (Director of Medical Services, 2006). Other species include $P$. malariae and $P$. ovale which sometimes occur as mixed infections with $P$. falciparum whilst $P$. vivax is very rare (Director of Medical Services, 2006). The prevalence of $P$. falciparum is reported to exceed $50 \%$ and the area is classified as a malaria endemic zone (Director of Medical Services, 2006). The inhabitants of the study area are generally poor and cannot afford conventional antimalarial drugs (Nguta et al., 2010a).

\section{METHODS}

Data on traditional knowledge of malaria diagnosis and ethnophytotherapeutic practices in three Digo villages was collected through survey employing semi-structured interviews and guided open and closed ended questionnaires (Huntington, 2000). The 
semi-structured interviews were conducted using a checklist of questions and were held with individuals and local area leaders. The questionnaire included questions on causes of malaria, known signs and symptoms of malaria, details of harvesting, preparation, and application of malaria herbal medicines. The questionnaire was translated into vernacular, ki-digo, the principal language spoken in the study area. Two group discussions that were held with community members complemented the interview and questionnaire survey, one in each of the study villages. Participants in the group discussions were identified by the local area leaders. Respondents for the questionnaire were selected randomly using the multi-stage random sampling method as follows: Diani location was selected from among the 11 locations of Msambweni district and was considered the primary sampling unit. Within Diani location, one sub-location (Ngombato) was selected. In turn, three villages of Mwamambi A, Mwamambi B, and Mwaroni were selected from Ngombato sub-location. The desired sample size was fixed at 60 respondents by assuming that $80 \%$ of the community had good knowledge regarding malaria diagnosis and its treatment; a desired confidence interval of $95 \%$; and a relative error of estimation of $10 \%$.

Thirty-two households were randomly selected from each village by consulting the village household registers. From among the selected households, a random sample of 16 households was picked from which men were to be interviewed while the remainder constituted the women respondents. In this way, a total of 40 respondents were interviewed in Mwamambi A and Mwamambi B villages and 20 from Mwaroni. The sample consisted of 34 male and 26 female respondents. Two guides identified with the help of the local leader were hired in each village to help locate the selected respondents and to introduce the team members to the respondents. All plant materials mentioned by respondents in the study were identified in the field. A voucher specimen of each species was collected for confirmation and deposited at the herbarium in the Department of Land Resources Management (LARMAT), University of Nairobi. Species nomenclature followed the flora for tropical East Africa (Nguta et al., 2010a). In addition, a written informed consent was obtained from the community representatives. The research objectives and methods were explained to respondents before every interview. At the end of the study, the findings were discussed with the community in a workshop.

\section{DATA ANALYSIS}

The comparative relative importance of each plant species and the collected ethnobotanical data was analyzed according to the method of Friedman et al. (1986) and this was used to determine the rank-order priority (ROP) depending on the proposed effectiveness of each plant. To reach this goal, the fidelity level (FL) of each plant was calculated as follows: $\mathrm{FL}=(\mathrm{lp} / \mathrm{lu}) \times 100$, where $\mathrm{lp}$ is the number of respondents who cited a given species and lu is the total number of respondents. Questionnaire survey data was entered in Excel spreadsheets. It was checked and edited for errors, and coded as described in Sarantakos (Nguta et al., 2010b). Thereafter, it was summarized using SPSS and reported in tables. Semi-structured interview data was studied and the responses grouped into classes expressing similar ideas.

\section{RESULTS}

\section{DIGO ETHNODIAGNOSTIC SKILLS}

Respondents had good knowledge about malaria and they could readily distinguish it from other fever types on the basis of accepted signs and symptoms. These included fever, chills, joint pains, weakness, headache, lethargy, abdominal pain, sneezing, and flu-like symptoms, loss of appetite, coughing, and vomiting (Table 1).

The respondents knew that mosquitoes were involved in transmission of malaria. They also reported that young children, pregnant mothers, individuals with malnutrition and those with diseases such as acquired immunodeficiency syndrome (AIDS) and tuberculosis were most commonly affected. However, some people thought that keeping a dirty homestead or drinking dirty water caused malaria, while some believed that it was caused by dense bush or pools of stagnant water close to their homesteads. Conditions likely to favor the breeding of mosquitoes were observed in all homesteads. Garbage, empty tins, tall grass, cattle sheds, and uncleared bushes were within $5 \mathrm{~m}$ of most homes. All homesteads had large plants within 3-5 $\mathrm{m}$ of the house as well as untreated stagnant water in the compound. Furthermore, many homesteads were in close proximity to wetlands and or open wells.

Table 1| Malaria symptoms mentioned by respondents $(n=20)$ in Diani location.

\begin{tabular}{ll}
\hline Symptom & $\begin{array}{l}\text { Percentage of respondents } \\
\text { citing the symptom }\end{array}$ \\
\hline Fever & 65 \\
Joint pains & 50 \\
Vomiting & 50 \\
Headache & 45 \\
High temperature & 40 \\
Chills & 35 \\
Shivering & 35 \\
Loss of appetite/anorexia & 30 \\
Diarrhea & 25 \\
Abdominal pain & 25 \\
Fatigue/lethargy & 20 \\
Sweating & 20 \\
Diagnosis from hospital & 15 \\
Confusion & 10 \\
Yellow eyes & 10 \\
Red eyes & 10 \\
Backache & 10 \\
Dizziness & 5 \\
Tiredness & 5 \\
Coughing & 5 \\
Scratching/itching & 5 \\
Pulsation of blood vessels & 5 \\
Weakness & 5 \\
Inability to stand & 5 \\
Abdominal disturbances & 5 \\
Extreme coldness & 5 \\
Flu-like symptoms/sneezing & 5 \\
Abdominal disturbances & 5 \\
Yellow vomit & 5 \\
& 5 \\
& 5 \\
\hline
\end{tabular}


A variety of strategies were employed by respondents to stop mosquito bites (Table 2). These included the use of mosquito nets and mosquito repellants such as mosquito coils, cleaning the environment, burning the leaves of fresh Azadirachta indica (L) Burm (20\%), burning the ripe seeds of Plectranthus barbatus Andr (25\%); burning stems of plants such as Ocimum bacilicum $\mathrm{L}$; burning the leaves of Ocimum suave Willd. (55\%) and also removing materials likely to promote the breeding of mosquitoes such as draining stagnant water $(30 \%)$ and treating water ponds with old engine oil (10\%). Respondents also reported that they cleared bushes around their homesteads to keep mosquitoes away from their houses. They also reported that they did cut grass around the homesteads (10\%). However, this was not observed during the study, and instead, bushes were always observed close to households.

\section{HERBAL MEDICINES USED TO TREAT MALARIA}

Sixty species distributed between 52 genera and 31 families were reportedly used in herbal preparations for the treatment of malaria (Table 3). The mode of preparation, voucher specimen number and the part of the medicinal plant used for preparation of antimalarial herbal remedy was documented (Table 3). Most of these species were woody plants (Shrubs and trees). Mature leaves were commonly used in the preparations. Respondents reported that the appropriate plant parts were collected as and when they were needed, and that there was no specific time to collect. They did not perform any rituals during collection or processing of herbal remedies.

The herbal remedies were prepared mostly as infusions, decoctions, or concoctions. The infusions and decoctions were prepared

Table 2 | Practices employed to guard against mosquito bites and/or to protect households against malaria $(n=20)$ by the Digo

community in Diani location.

Practice

Taking herbal remedies

Burning plants to repel mosquitoes, e.g., Ocimum bacilicum L.

Clearing bushes around homesteads

Use of mosquito nets

Cleaning the environment

Draining stagnant water

Burning the ripe seeds or fruits of Plectranthus barbatus Andr.

Burning the fresh leaves of Azadirachta indica (L) Burm

Garbage collection

Treating stagnant water with old engine oil

Cutting tall grass around homesteads

Treating drinking water

Boiling drinking water

Burning mosquito coil

Burning garbage/bushes

Cleanliness

Planting mosquito repellant trees around the homestead

Constructing cattle sheds far from homesteads

Burning the leaves of Ocimum suave Willd.

Treating drinking water with water guard as mono-preparations from single plant species. The preparations were mostly administered orally and also at times topically as steam baths. Oral doses were variable and were administered according to the age of the patient. They varied between 80 and $500 \mathrm{ml}$ for adults; 80 and $125 \mathrm{ml}$ for older children (more than 5 years) and $1-$ 3 tablespoons for children younger than 5 years. The herbal drugs were taken 1-3 times a day for a period of 3-5 days. Prepared herbal remedies were consumed immediately and never kept. The preparation that remained after use was discarded. There was no need to keep any since the plants from which they were produced from were readily accessible. Respondents who used herbal remedies indicated that they were effective and had no side effects if the correct dose was taken.

\section{DISCUSSION}

\section{DIGO ETHNODIAGNOSTIC SKILLS}

One of the objectives of the current study was to document the ethnodiagnostic skills utilized by the Digo community to diagnose malaria. Indeed, researchers need to document how people describe the signs (or symptoms) of illnesses (Heinrich et al., 2009). The study community has developed abundant ethnodiagnostic skills for malaria which forms the basis of their traditional bioprospecting techniques. The respondents interviewed in the current study had good knowledge about malaria and readily distinguished it from other illnesses on the basis of widely accepted malaria signs and symptoms (Tabuti, 2008). The community recognized that the clinical features of uncomplicated and severe malaria included chills, profuse sweating, joint pains, abdominal pain, diarrhea, vomiting, anorexia, and inability to stand. Malaria continues to be a major health challenge in Kenya especially due to the emergence of parasite resistance to the commonly used and relatively cheap antimalarials. Knowledge about malaria has steadily improved in Kenya, but some misconceptions still remain about the causes and symptoms of severe malaria, and this were also documented in this study. However, majority of the respondents knew that malaria was spread by mosquitoes and one of the major symptoms of the disease was fever. This relatively good understanding of the causes and signs of the disease may help in the implementation of intervention measures aimed at reducing its incidence and prevalence since the Digo knowledge about the transmission and major symptoms of disease are congruent with science and they do not associate it with witchcraft, as do some communities elsewhere (Nuwaha, 2002).

\section{HERBAL MEDICINES USED BY THE DIGO COMMUNITY TO TREAT MALARIA}

Antimalarial plant species in the study area are the dominant commercial element as they are sought by a wider spectrum of the society. Most of the plants collected have been reported in the literature, as having been used for malaria or fever (Table 4), an indication that the community could be trusted for the information they imparted about the plants they use. The results of the current study show that a large number of medicinal plants are traditionally used for treatment of malaria among the Digo community. Sixty species in 52 genera and 27 families were 
Table 3 Plant species commonly reported by Digo people for the treatment of malaria in Diani location $(n=60)$.

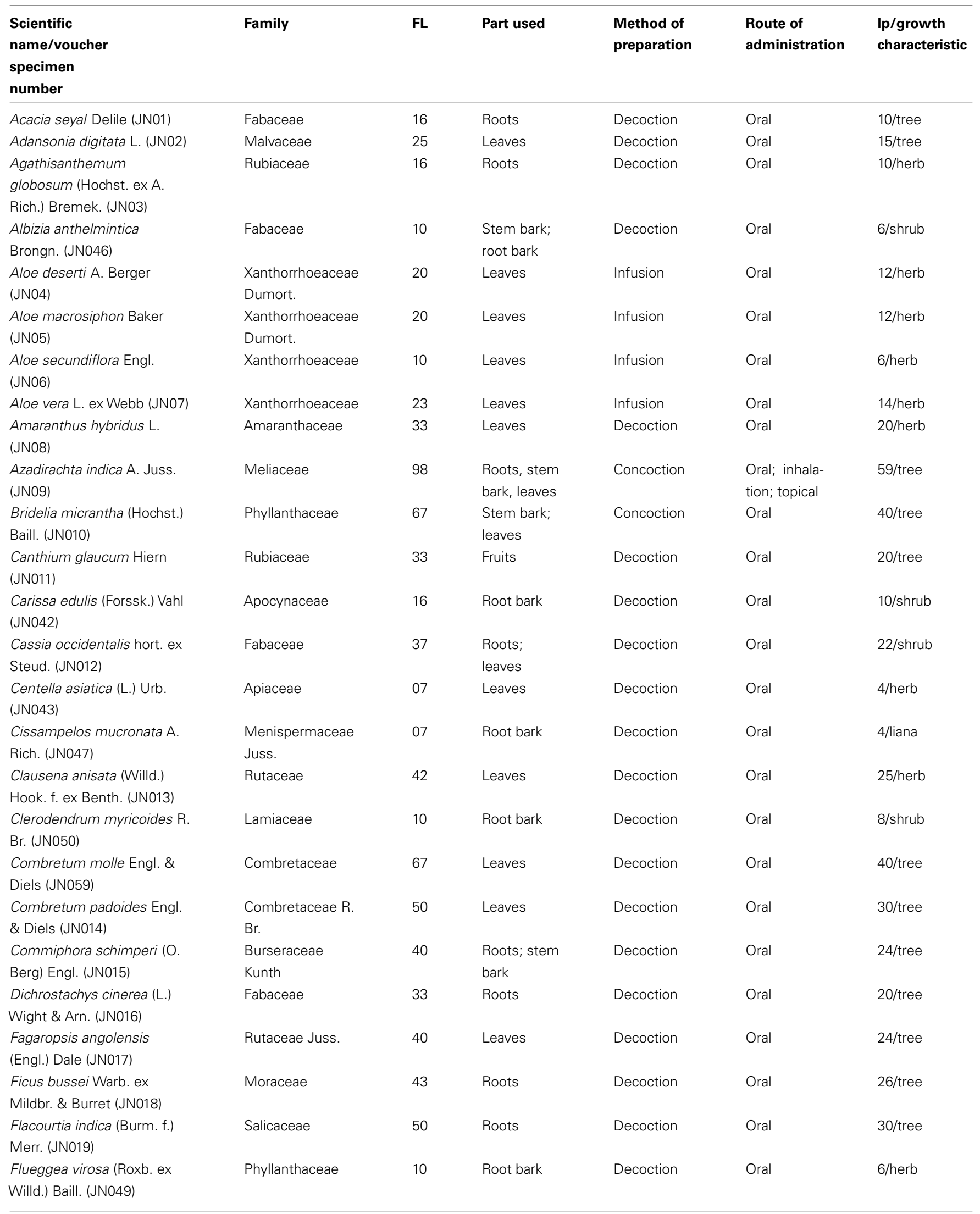


Table 3 | Continued

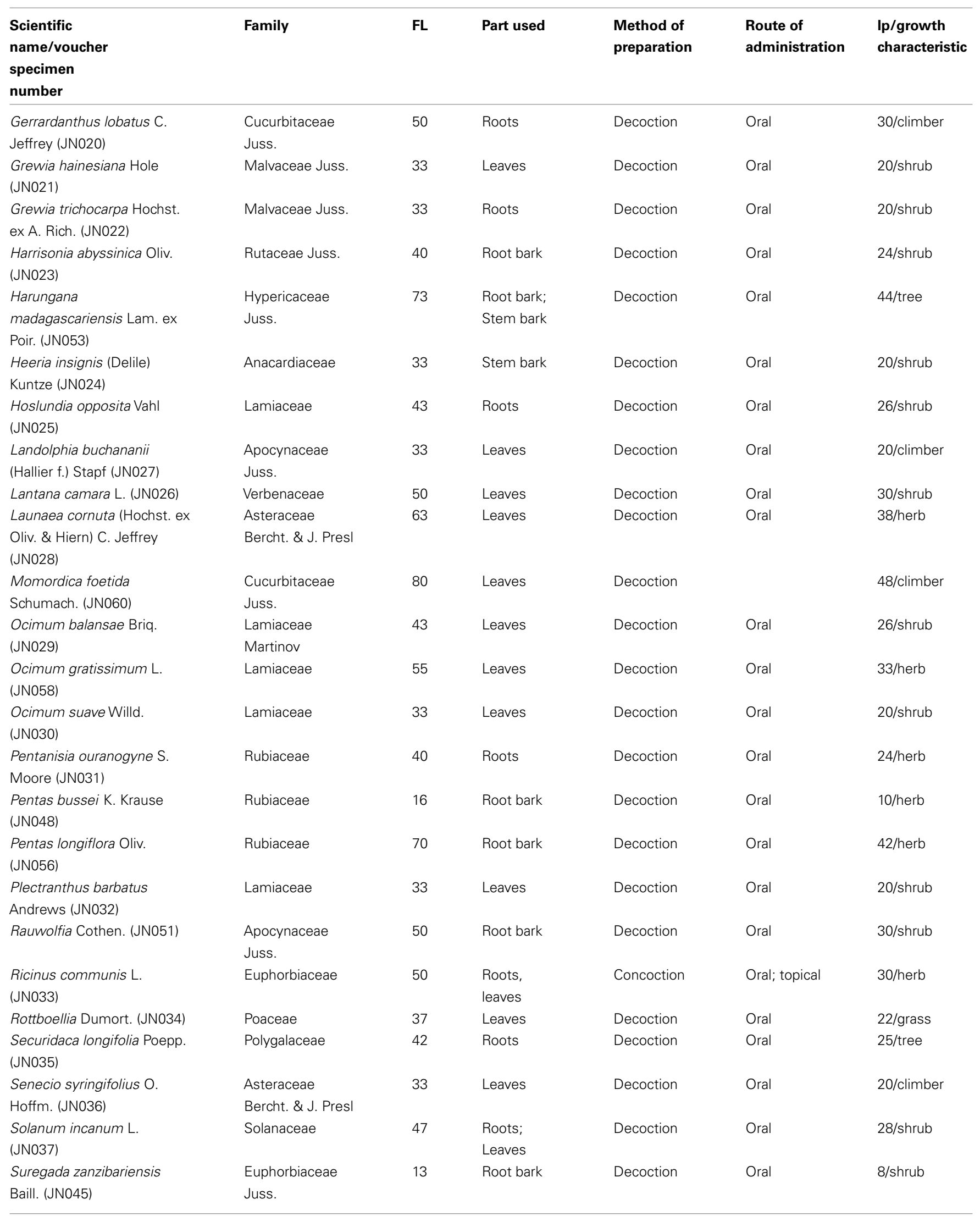


Table 3 | Continued

\begin{tabular}{|c|c|c|c|c|c|c|}
\hline $\begin{array}{l}\text { Scientific } \\
\text { name/voucher } \\
\text { specimen } \\
\text { number }\end{array}$ & Family & $\mathbf{F L}$ & Part used & $\begin{array}{l}\text { Method of } \\
\text { preparation }\end{array}$ & $\begin{array}{l}\text { Route of } \\
\text { administration }\end{array}$ & $\begin{array}{l}\text { Ip/growth } \\
\text { characteristic }\end{array}$ \\
\hline Tamarindus indica L. (JN038) & Fabaceae Lindl & 33 & $\begin{array}{l}\text { Roots; } \\
\text { leaves }\end{array}$ & Decoction & Oral & 20/tree \\
\hline $\begin{array}{l}\text { Teclea simplicifolia (Engl.) I. } \\
\text { Verd. (JN039) }\end{array}$ & Rutaceae Juss. & 43 & $\begin{array}{l}\text { Roots \& } \\
\text { Decoction }\end{array}$ & Oral & 26/shrub & \\
\hline $\begin{array}{l}\text { Terminalia spinosa Northr. } \\
\text { (JN052) }\end{array}$ & Combretaceae & 66 & Stem bark & $\begin{array}{l}\text { Cold water } \\
\text { infusion }\end{array}$ & Oral & 40/tree \\
\hline $\begin{array}{l}\text { Toddalia asiatica (L.) Lam. } \\
\text { (JN055) }\end{array}$ & Rutaceae & 58 & Root bark & Decoction & Oral & 35/shrub \\
\hline $\begin{array}{l}\text { Tridax procumbens L. } \\
\text { (JN054) }\end{array}$ & Asteraceae & 47 & Whole plant & $\begin{array}{l}\text { Cold water } \\
\text { infusion }\end{array}$ & Oral & 28/herb \\
\hline $\begin{array}{l}\text { Warburgia stuhlmannii Engl. } \\
\text { (JN044) }\end{array}$ & Canellaceae Mart. & 20 & Stem bark & Decoction & Oral & $12 /$ tree \\
\hline $\begin{array}{l}\text { Zanthoxylum chalybeum } \\
\text { Engl. (JN040) }\end{array}$ & Rutaceae & 53 & Root bark & Decoction & Oral & $32 /$ tree \\
\hline
\end{tabular}

$F L$ is the fidelity level.

Ip is the number of respondents citing each species.

$\mathrm{Lu}$ is the total number of respondents (60).

Decoction is a method of preparation in which the plant part is boiled in water.

Concoction is a method of preparation in which more than one plant part is boiled in water.

Infusion is a method of preparation that involves soaking of a plant part in water.

documented. Lamiaceae ( aceae (five species), and Fabaceae (five species) families represented the species most commonly cited. Studies from other regions of Africa indicate Rubiaceae to have many species used in the management of malaria in different countries (Iwu, 1994). This was consistent with our results but Rutaceae had a higher number of species (six species) cited as sources of antimalarial remedies compared to Rubiaceae (five species; Table 4), which would indicate the importance of this family as a possible source of antimalarial plants. The information on frequently utilized antimalarial plant species is also an important lead to the species that can be targeted for antiplasmodial tests, toxicological tests, and phytochemical analysis. Since there is no safer, effective, and cheaper antimalarial remedy than chloroquine in the treatment of malaria, development of new antimalarial drugs from plant sources may be the way forward in dealing with global drug-resistant problems of malaria (Gessler et al., 1995). Natural products and their derivatives represent over $50 \%$ of all the drugs in clinical use in the world (Van Wyk et al., 2002). The results of this study show that both indigenous and introduced species are in use for malaria treatment. This indicates that traditional medicinal practices in this region are dynamic, and this could be influenced by modern communication and informal information exchange between people.
In Africa, herbal medicines are an important part of the culture and traditions of its people and biodiversity. Herbal remedies have played major specific roles in the cultural evolution of human societies (Mugabe and Clark et al., 1998). Apart from their cultural significance, traditional medicines have been accessible and affordable and most people in Kenya especially in rural areas use traditional medicine and medicinal plants to treat many diseases including malaria (Njoroge and Bussmann, 2006). The role of ethnopharmacology is to give direction on the plant species for selection as well as data for plant preparation, posology, effects, and side effects which could provide specific targets for isolation of active compounds and pharmacological investigation in the quest for development of new pharmaceuticals (Cox and Balick, 1994). Recent work on African plants used in the treatment of malaria is very encouraging. It is striking how many different plants are reported by communities and herbalists to cure malaria. The challenge will be to translate herbal medicine practice with these plants into an evidence-based monotherapy or combined therapy as suggested by Rasoanaivo et al. (1999). There is need therefore, to corroborate with communities, traditional healers, and clinicians for observational retrospective treatmentoutcome and prospective clinical study of a traditional medicine. The administration of a traditional treatment (e.g., a plant preparation) as a decoction/concoction, and the systematic follow up of the outcome in a clinical study with the effect of a rapid and 
Table 4 | Plants used by the Digo community to treat malaria and the published evidence of their activities and/or other uses.

\begin{tabular}{|c|c|c|c|c|c|}
\hline Family & $\begin{array}{l}\text { Species/voucher } \\
\text { specimen } \\
\text { number }\end{array}$ & $\begin{array}{l}\text { Traditional } \\
\text { treatment }\end{array}$ & $\begin{array}{l}\text { Plant part } \\
\text { used }\end{array}$ & $\begin{array}{l}\text { Bioactive or } \\
\text { potentially active } \\
\text { compounds }\end{array}$ & Screened activity \\
\hline Anacardiaceae & $\begin{array}{l}\text { Heeria insignis (Delile) } \\
\text { Kuntze (JN024) }\end{array}$ & $\begin{array}{l}\text { Epilepsy (Moshi et al., } \\
\text { 2005) }\end{array}$ & Stem bark & $\begin{array}{l}\text { Myrcene, } \beta \text {-pinene, } \alpha \text { - } \\
\text { pinene (Ayedoun et al., } \\
\text { 1998) }\end{array}$ & Not screened \\
\hline Annonaceae Juss. & $\begin{array}{l}\text { Uvaria scheffleri Diels } \\
\text { (JN041) }\end{array}$ & $\begin{array}{l}\text { Malaria (Kokwaro, 1993; } \\
\text { Beentje, 1994) }\end{array}$ & Leaves & $\begin{array}{l}\text { Indole } \\
\text { alkaloid-(DL)-schefflone } \\
\text { (Nkunya et al., 2004) }\end{array}$ & $\begin{array}{l}\text { Antiplasmodial activity } \\
\text { (Nkunya et al., 1991) }\end{array}$ \\
\hline Apiaceae & $\begin{array}{l}\text { Centella asiatica (L.) Urb. } \\
\text { (JN043) }\end{array}$ & Fever (Manandhar, 1993) & Leaves & $\begin{array}{l}\text { Alkaloids, } \\
\text { Sesquiterpenes } \\
\text { (Holeman et al., 1994) }\end{array}$ & $\begin{array}{l}\text { Antiplasmodial activity } \\
\text { (Clarkson et al., 2004) }\end{array}$ \\
\hline Apocynaceae Juss. & $\begin{array}{l}\text { Landolphia buchananii } \\
\text { (Hallier f.) Stapf (JN027) }\end{array}$ & $\begin{array}{l}\text { Malaria (Nguta et al., } \\
\text { 2010a,2010b) }\end{array}$ & Leaves & Not identified & Not screened \\
\hline Apocynaceae Juss. & $\begin{array}{l}\text { Rauwolfia Cothen. } \\
\text { (JN051) }\end{array}$ & $\begin{array}{l}\text { Malaria (Kokwaro, 1993; } \\
\text { Beentje, 1994) }\end{array}$ & Root bark & $\begin{array}{l}\text { Yohimbine-an indole } \\
\text { alkaloid (Iwu and Court, } \\
\text { 1979) }\end{array}$ & $\begin{array}{l}\text { Antiplasmodial activity } \\
\text { Weenen et al., 1990) }\end{array}$ \\
\hline Asteraceae & $\begin{array}{l}\text { Vernonia amygdalina A. } \\
\text { Chev. (JN057) }\end{array}$ & $\begin{array}{l}\text { Malaria (Asase et al., } \\
\text { 2005) }\end{array}$ & Leaves & Not identified & $\begin{array}{l}\text { Antiplasmodial activity } \\
\text { (Tona et al., 2004) }\end{array}$ \\
\hline Asteraceae & $\begin{array}{l}\text { Tridax procumbens L. } \\
\text { (JN054) }\end{array}$ & $\begin{array}{l}\text { Malaria and stomachache } \\
\text { (Kokwaro, 1993) }\end{array}$ & Whole plant & $\begin{array}{l}\text { Cpd-bergenin (Akbar } \\
\text { et al., 2002) }\end{array}$ & $\begin{array}{l}\text { Antimalarial activity Wee- } \\
\text { nen et al., 1990; Clarkson } \\
\text { et al., 2004) }\end{array}$ \\
\hline $\begin{array}{l}\text { Asteraceae Bercht. } \\
\& \text { J. Presl }\end{array}$ & $\begin{array}{l}\text { Launaea cornuta (Hochst. } \\
\text { ex Oliv. \& Hiern) C. } \\
\text { Jeffrey (JN028) }\end{array}$ & Typhoid (Kokwaro, 1993) & Leaves & $\begin{array}{l}\text { Tannins and astringents } \\
\text { (Burkill, 1985) }\end{array}$ & Not screened \\
\hline Canellaceae Mart. & $\begin{array}{l}\text { Warburgia stuhlmannii } \\
\text { Engl. (JN044) }\end{array}$ & $\begin{array}{l}\text { Tooth ache and } \\
\text { rheumatism (Beentje, } \\
\text { 1994) }\end{array}$ & Stem bark & $\begin{array}{l}\text { Sesquiterpenes } \\
\text { (Manguro et al., 2003) }\end{array}$ & $\begin{array}{l}\text { Antibacterial, Bacillus } \\
\text { subtilis (Taniguchi et al., } \\
\text { 1978) }\end{array}$ \\
\hline Combretaceae & $\begin{array}{l}\text { Terminalia spinosa Northr. } \\
\text { (JN052) }\end{array}$ & Jaundice (Beentje, 1994) & Stem bark & Not identified & $\begin{array}{l}\text { Antiplasmodial activity } \\
\text { (Omulokoli et al., 1997) }\end{array}$ \\
\hline Combretaceae & $\begin{array}{l}\text { Combretum molle Engl. } \\
\text { \& Diels (JN059) }\end{array}$ & Malaria (Tabuti, 2008) & Leaves & Not identified & Not screened \\
\hline $\begin{array}{l}\text { Combretaceae R. } \\
\text { Br. }\end{array}$ & $\begin{array}{l}\text { Combretum padoides } \\
\text { Engl. \& Diels (JN014) }\end{array}$ & $\begin{array}{l}\text { Hookworms (Neuwinger, } \\
\text { 2000) }\end{array}$ & Leaves & $\begin{array}{l}\text { Mono and bi-desmosidic } \\
\text { triterpenoids from leaves } \\
\text { (Rodgers and Coombes, } \\
\text { 1999) }\end{array}$ & $\begin{array}{l}\text { antimicrobial } \\
\text { (Eloff, 1999) }\end{array}$ \\
\hline $\begin{array}{l}\text { Cucurbitaceae } \\
\text { Juss. }\end{array}$ & $\begin{array}{l}\text { Gerrardanthus lobatus C. } \\
\text { Jeffrey (JN020) }\end{array}$ & $\begin{array}{l}\text { Malaria (Nguta et al., } \\
\text { 2010a) }\end{array}$ & Roots & $\begin{array}{l}\text { Flavonoids (Imperato, } \\
\text { 2005) }\end{array}$ & Not screened \\
\hline $\begin{array}{l}\text { Cucurbitaceae } \\
\text { Juss. }\end{array}$ & $\begin{array}{l}\text { Momordica foetida } \\
\text { Schumach. (JN060) }\end{array}$ & $\begin{array}{l}\text { Malaria (Gessler et al., } \\
\text { 1995) }\end{array}$ & Leaves & Not identified & $\begin{array}{l}\text { Antimalarial activity } \\
\text { Maako et al., 2005) }\end{array}$ \\
\hline Euphorbiaceae & $\begin{array}{l}\text { Ricinus communis L. } \\
\text { (JN033) }\end{array}$ & $\begin{array}{l}\text { Antimalarial agent } \\
\text { (Burkill, 1935); fever } \\
\text { (Burkill, 1994) }\end{array}$ & Roots; leaves & Not identified & $\begin{array}{l}\text { Antiplasmodial activity } \\
\text { (Clarkson et al., 2004) }\end{array}$ \\
\hline $\begin{array}{l}\text { Euphorbiaceae } \\
\text { Juss. }\end{array}$ & $\begin{array}{l}\text { Suregada zanzibariensis } \\
\text { Baill. (JN045) }\end{array}$ & $\begin{array}{l}\text { Malaria (Chhabra et al., } \\
\text { 1990) }\end{array}$ & Root bark & $\begin{array}{l}\text { Alkaloids (Smolenski } \\
\text { et al., 1975) }\end{array}$ & $\begin{array}{l}\text { Antiplasmodial activity } \\
\text { (Omulokoli et al., 1997) }\end{array}$ \\
\hline
\end{tabular}


Table 4 | Continued

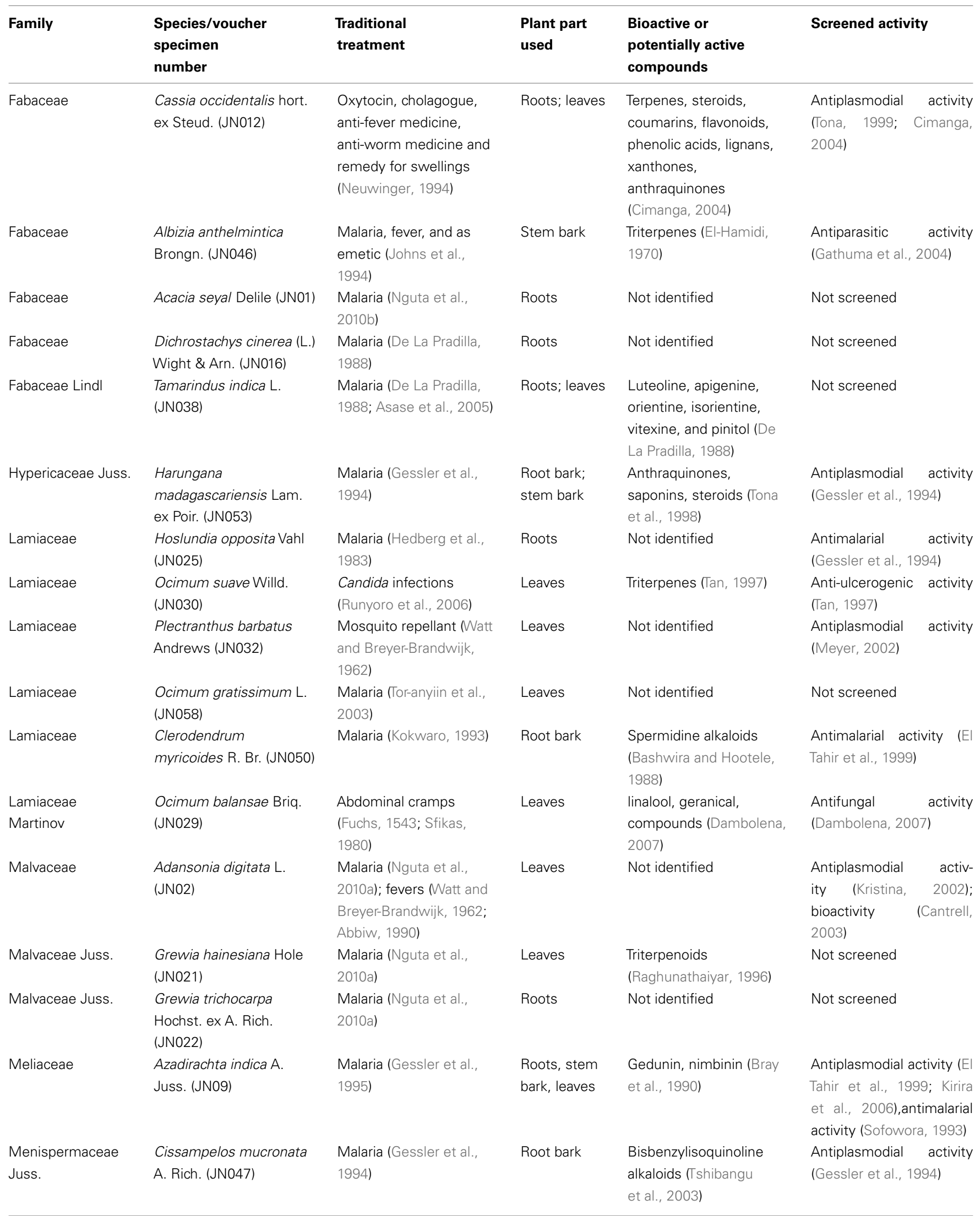


Table 4 | Continued

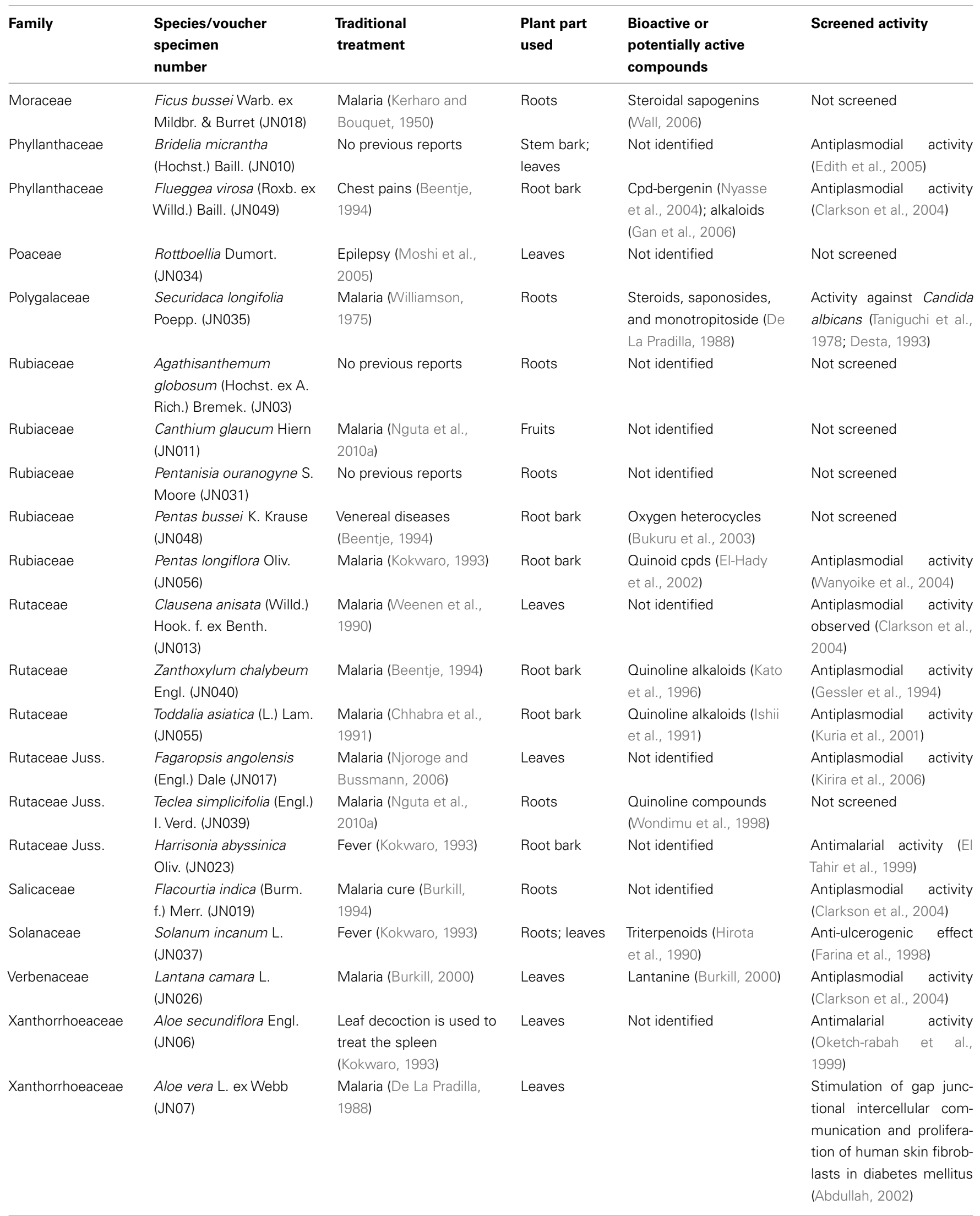


Table 4 | Continued

\begin{tabular}{|c|c|c|c|c|c|}
\hline Family & $\begin{array}{l}\text { Species/voucher } \\
\text { specimen } \\
\text { number }\end{array}$ & $\begin{array}{l}\text { Traditional } \\
\text { treatment }\end{array}$ & $\begin{array}{l}\text { Plant part } \\
\text { used }\end{array}$ & $\begin{array}{l}\text { Bioactive or } \\
\text { potentially active } \\
\text { compounds }\end{array}$ & Screened activity \\
\hline $\begin{array}{l}\text { Xanthorrhoeaceae } \\
\text { Dumort. }\end{array}$ & $\begin{array}{l}\text { Aloe deserti A. Berger } \\
\text { (JN04) }\end{array}$ & $\begin{array}{l}\text { A leaf decoction is used } \\
\text { to treat the spleen } \\
\text { (Kokwaro, 1993) }\end{array}$ & Leaves & $\begin{array}{l}\text { Anthrone C-glycosides, } \\
\text { chromones, and phenolic } \\
\text { compounds (Reynolds, } \\
\text { 2008) }\end{array}$ & Not screened \\
\hline $\begin{array}{l}\text { Xanthorrhoeaceae } \\
\text { Dumort. }\end{array}$ & $\begin{array}{l}\text { Aloe macrosiphon Baker } \\
\text { (JN05) }\end{array}$ & $\begin{array}{l}\text { A leaf decoction is used } \\
\text { to treat the spleen } \\
\text { (Kokwaro, 1993) }\end{array}$ & Leaves & Not identified & Not screened \\
\hline
\end{tabular}

complete cure, without failure and or serious side effects, would lead to further research of the product with a view to isolating active constituents that would form the basis of a monotherapy or combination therapy.

Within a context of growing antimalarial resistance and the difficulties for households to afford and access effective antimalarials, the development, and promotion of phytomedicines may be the only sustainable solution to malaria treatment (Tabuti, 2008). This focus is justified because herbal medicines are widely accepted as safe and efficacious remedies by the study community. Indeed many drugs used in malaria treatment have been derived from higher plants using leads from traditional knowledge (Van Wyk and Wink, 2004). These include the quinoline based antimalarials as well as artemisinin and its derivatives (Waako et al., 2005).

There are species, which were commonly cited in this study that are used as antimalarial remedies in other parts of Kenya or other countries. This convergence in use of the same species in different cultures over a long period suggests strongly that these species may be effective in the treatment of malaria (Van Wyk and Wink, 2004). It is however, important to validate all claims of therapeutic efficacy and safety by undertaking pharmacological, toxicological, and controlled clinical studies. Validation of traditional medicinal practices is important because it may generate higher confidence and hence wider use of such species. Wider acceptance of traditional herbal remedies can yield significant benefits for primary health care and also extend the market and possibility for value addition of an herbal medicine. Validations may proceed from observations of the treatment responses among patients taking the herbal medicines (Diallo and Paulsen, 2000). Promising herbal medicines identified in this way can then be subjected to pharmacological screening, toxicological screening, phytochemical analysis, and clinical trials to confirm their efficacy and safety, and also determine administration doses (World Health Organization, 2000).

\section{REFERENCES}

Abbiw, D. K. (1990). Useful Plants of Ghana. London: Intermediate Technology Publications and The Royal Botanical Gardens, 154-157.

Abdullah, K. M. (2002). Effects of Aloe vera on gap junctional intercellular communication and proliferation of human diabetic and nondiabetic skin fibroblasts. Exp. Clin. Endocrinol. 110, 176-185.

Achenbach, H., Waibel, R., and AddaeMensah, I. (1985). Sesquiterpenes from Carissa edulis. Phytochemistry 24, 2325-2328.

\section{CONCLUSION}

Many plant species reported in this study have been investigated for their phytoconstituents (53\%) and pharmacological activities $(65 \%)$, the latter are in agreement with ethnopharmacological uses reported in this paper. Lamiaceae and Rutaceae represent families with commonly cited species. In Msambweni district, traditional methods of treatments based on medicinal plants are still an important part of social life and culture and the acceptability of these plants as claimed effective remedies is quite high among the population of this area. There is a very high probability of discovering new medicines from bioprospecting activities because the Digo ethnomedical practice is well developed and compares favorably with modern medical practice. The Digo ethnomedicine depends on an elaborate indigenous knowledge of malaria diagnostic procedure and medicinal plants used to treat the disease which is endemic in South Coast, Kenya. The claimed therapeutic value of the reported species call for modern scientific studies to establish their safety and efficacy and to preserve and document this flora which may otherwise be lost due to erosion of age old traditional methods of biodiversity conservation and medicinal knowledge. It is concluded that, the Digo ethnodiagnostic skill is the basis of their traditional bioprospecting techniques.

The local community of South Coast, Kenya is the owner of the traditional knowledge presented in this paper; consequently, any benefits that may accrue from the use of this knowledge must be shared with them.

\section{ACKNOWLEDGMENTS}

The authors acknowledge financial support from the Carnegie Corporation of New York through Regional Initiative in Science and Education African Natural Product Training Network (RISE-AFNNET). Technical support in identification of voucher specimens by Mr. Kimeu Musembi of Nairobi University Herbarium (LARMAT) is acknowledged. We also thank the community of South Coast, Kenya, for sharing their knowledge and time with us.

Akbar, E., Malik, A., Afza, N., and Hai, S. M. A. (2002). Flavone glycosides and bergenin derivatives from Tridax procumbens. Heterocycles 57, 733-739.

Asase, A., Oteng-Yeboaha, A. A. Odamttena, G. J., and Simmonds, M. S. I. (2005). Ethnobotanical study of some Ghananian antimalarial plants. J. Ethnopharmacol. 99, 273-279.

Ayedoun, M. A., Moudachirou, M., Garnau, F. X., Gagnon, H., Jean, F. I., Tomi, F., and Cassanova, J. (1998). Chemical composition of leaf and flower oils of Heeria insignis Del. 
from Benin. J. Essent. Oil Res. 10, 529-530.

Bashwira, S., and Hootele, C. (1988). Myricoidine and dihydromyricoidine, two new macrocyclic spermidine alkaloids from Clerodendrum myricoides. Tetrahedron 44, 4521-4526.

Beentje, H. J. (1994). Kenya Trees, Shrubs and Lianas. Nairobi: National Museums of Kenya.

Bray D. H., Warhurst, D. C., Connolly, J. D., Rsquo, O., Neill, M. J., and Phillipson, J. D. (1990). Plants as source of antimalarial drugs. Pt 7 activity of some Meliaceae plants and their constituent limonoids. Phytother. Res. 4, 29-35.

Bukuru, J. F., Van Nguyen, T., Van Puyvelde, I., He, W. D., and De, Kimpe, N. (2003). New pentacyclic cyclol-type napthohydroquinone from the roots of Pentas bussei. Tetrahedron 59, 5905-5908.

Burkill, H. R. M. (1935). A Dictionary of the Economic Products of the Malay Peninsula. London: Crown Agents for the Colonies.

Burkill, H. R. M. (1985). The Useful Plants of West Tropical Africa, Vol. 1. London: Royal Botanic Gardens.

Burkill, H. R. M. (1994). The Useful Plants of West Tropical Africa, Vol. 2. London: Royal Botanic Gardens.

Burkill, H. R. M. (2000). The Useful Plants of West Tropical Africa, Vol. 5. London: Royal Botanic Gardens.

Cantrell. (2003). Bioactive crude plant seed extracts from the NCAUR oil seed repository. Phytomedicine 10, 325-333.

Chhabra, S. C., Mahunnah, R. L. A., and Mshiu, E. N. (1990). Plants used in traditional medicine in Eastern Tanzania. III. Angiosperms (Euphorbiaceae to Menispermaceae). J. Ethnopharmacol. 28, 255-283.

Chhabra, S. C., Mahunnah, R. L. A., and Mshiu, E. N. (1991). Plants used in traditional medicine in Eastern Tanzania. V. Angiosperms (Passifloraceae to Sapindaceae). J. Ethnopharmacol. 33, 143-157.

Cimanga, R. K. (2004). In vitro antiplasmodial activity of extracts and fractions from seven medicinal plants used in the Democratic Republic of Congo. J. Ethnopharmacol. 93, 27-32.

Clarkson, C., Vineshm, J. M., Neil, R. C., Olwen, M. G., Pamisha, P., Motlalepula, G. M., Niresh, B., Peters, J. S., and Peter, I. F. (2004). In vitro antiplasmodial activity of medicinal plants native to or naturalized in South Africa. J. Ethnopharmacol. 92, 177-191.
Cox, P. A., and Balick, M. J. (1994). The ethnobotanical approach to drug discovery. Phytochemistry. 270, 60-65.

Dambolena, J. S. (2007). 12th Symposium of the Natural Product Research Network for Eastern and Central Africa (NAPRECA), Kampala.

De La Pradilla, C. F. (1988). Plantes Medicinales contre le paludisme. Barcelona: ined.ms.

Desta, B. (1993). Ethiopian traditional herbal drugs. Part II. Antimicrobial activity of 63 medicinal plants. J. Ethnopharmacol. 39, 129-139.

Diallo, D., and Paulsen, B. S. (2000). "Pharmaceutical research and traditional practitioners in mali: experiences with benefit sharing," in Responding to Bioprospecting: from Biodiversity in the South to Medicines in the North, eds H. Svarstad and S.S. Dhillion (Oslo: Spartacus Forlag As), 133-144.

Director of Medical Services. (2006). Figures provided by Director of Medical Services of Kenya as reported in the local press, Kenya.

Edith, A., Joseph, A., Oyindamola, A. Larry, O., Omonike, O., Dora, A., Catherine, F., Olayinka, B., Grace, G., Mofusho, F., Oludele, L., Peter, H., Collins, W., and Ayoade, O. (2005). Antimalarial ethnobotany: in vitro antiplasmodial activity of seven plants identified in the Nigerian Middle Belt. Pharm. Biol. 42, 588-591.

El Tahir, A., Satti, G. M. H., and Khalid, S. A. (1999). Antiplasmodial activity of selected Sudanese medicinal plants with emphasis on Maytenus senegalensis (Lam.) excell. J. Ethnopharmacol. 64, 227-233.

El-Hady, S., Bukuru, J., Kesteleyn, B., Van Puyvelde, L., Van, T. N., and Kimpe, N. (2002). New pyranonapthohydroquinone and pyranonapthohydroquinone from the roots of Pentas longiflora. J. Nat. Prod. 65, 1377-1379.

El-Hamidi, A. (1970). Drug plants of the Sudan Republic in native medicine. Planta Med. 18, 278.

Eloff, J. N. (1999). The antibacterial activity of 27 Southern African members of the Combretaceae. $S$. Afr. J. Sci. 95, 148-152.

Farina, C., Pinza, M., and Pifferi, G. (1998). Synthesis and antiulcer activity of new derivatives of glycyrrhetic, oleanolic and ursolic acids. Farmaco 53, 22-32.

Foster, S. D. (1991). Pricing, distribution and use of antimalarial drugs. Bull. World Health Organ. 69, 349-363.
Friedman, J., Yaniv, Z., Dafni, D., and Palevitch. (1986). A preliminary classification of the healing potential of medicinal plants based on a rational analysis of an ethnopharmacological field survey among Bedouins in the Negev desert, Israel. J. Ethnopharmacol. 16, 275-278.

Fuchs, L. (1543). Krauterbuch. Basel: Michael Insigrin.

Gan, L. S., Fan, C. Q., Yang, S. P., Wu, Y., Lin, L. P., Ding, J., and Yue, J. M. (2006). Flueggenines A and B, two novel C, C-linked dimerin indolizidine alkaloids from Flueggea virosa. Org. Lett. 8, 2285-2288.

Gathuma, J. M., Mbaria, J. M. Wanyama, J., Kaburia, H. F. A. Mpoke, L., Mwangi, J. N., and Healers, S. T. (2004). Efficacy of Myrsine africana, Albizia anthelmintica and Hilderbrantia sepalosa herbal remedies against natural sheep helminthosis in Samburu district, Kenya. J. Ethnopharmacol. 91, 7-12.

Gessler, M. C., Mysuya, D. E., Nkunya, M. H. H., Mwasumbi, L. B., Schar, A., Heinrich, M., and Tanner, M. (1995). Traditional healers in Tanzania: the treatment of malaria with plant remedies. J. Ethnopharmacol. 48, 119-130.

Gessler, M. C., Nkunya, M. H. H., Mwasumbi, L. B., Schar, A., Heinrich, M., and Tanner, M. (1994). Screening Tanzanian medicinal plants for antimalarial activity. Acta Trop. 56, 65-77.

Hedberg, I., Hedberg, O., Madati, P. J., Mshingeni, K. E., Mshiu, E. N. and Samuelson, G. (1983). Inventory of plants used in traditional medicine in Tanzania. Part III Plants of the families PapilionaceaeVitaceae. J. Ethnopharmacol. 9, 237-260.

Heinrich, M., Edwards, S., Moerman, D. E., and Leonti, M. (2009). Ethnopharmacological field studies: a critical assessment of their conceptual basis and methods. J. Ethnopharmacol. 124, 1-17.

Hirota, M., Mori, T., Yoshinda, M., and Iriye, R. (1990). Search for new lead compounds from higher plants. $J$. Agric. Biol. And Chem. 54, 1073.

Hoffman, S. L., Gardner, M. J., Doolan, D. L., Hedstrom, R. C., Wang, R., Sedegah, M., Gramzinski, R. A., Aguiar, J. C., Wang, H., Margalith, M., and Hobart, P. (1996). DNA vaccines against malaria: immunogenicity and protection in a rodent model. J. Pharm. Sci. 85, 1294-1300.

Holeman, M., Theron, E., and Pinel, R. (1994). Centella asiatica analyses by
GC-MS and infra red Ms. Parfums Cosmet. Aromes 120, 52-55.

Huntington, H. P. (2000). Using traditional ecological knowledge in science: methods and applications. Ecol. Appl. 10, 1270-1274.

Imperato, F. (2005). Five plants of the family Cucurbitaceae with flavonoid patterns of pollens different from those of corresponding stigmas. Phytother. Res. 36, 1136-1137.

Ishii, H., Koyabashi, J., and Ishikawa, T. (1991). Toddacoumalone, a novel mixed dimer of coumarin and quinolone from Toddalia asiatica (L.) Lam. (T. aculeata Pers). Tetrahedron Lett. 32, 6907-6910.

Iwu, M. M. (1994). "African medicinal plants in the search for new drugs based on ethnobotanical leads," in Ethnobotany and Search for New Drugs, eds D. J. Chadwick and J. Marsh (Chichester: Wiley) 116-129.

Iwu, M. M., and Court, W. E. (1979). Alkaloids of Rauwolfia mombasiana stem bark. Planta Med. 36, 208-212.

Jean-Marie, K. (2002). Changing National Malaria Treatment Protocols in Africa, Nairobi: Press Dossier.

Johns, T., Mhoro, E. B., Sanaya, P., and Kimanani, E. K. (1994). Herbal remedies of the Batemi of Ngorongoro district, Tanzania: a quantitative appraisal. Econ. Bot. 48, 90-95.

Kato, A., Moriyasu, M., Ichimaru, M., Nishiyama, Y., Juma, F. D., Nganga J. N., Mathenge, S. G., and Ogeto, J. Q. (1996). Isolation of alkaloidal constituents of Zanthoxylum usambarense and Zanthoxylum chalybeum using ion pair HPLC. J. Nat. Prod. 59, 316-318.

Kerharo, J., and Bouquet, A. (1950). Plantes Medicinales \& Toxiques de la Cote-d'Ivoire-Haute-Volta. Paris: Vigot Freres.

Khaemba, B. M., Mutani, A., and Bett, M. K. (1994). Studies of anopheles mosquitoes transmitting malaria in a newly developed highland urban area: a case study of Moi University and its environs. East Afr. Med. J. 71, 159-164.

Kirira, P. G., Rukunga, G. M., Wanyonyi, A. W., Muregi, F. M., Gathirwa, J. W., Muthaura, C. N., Omar, S. A., Tolo, F., Mungai, G. M., and Ndiege, I. O. (2006). Antiplasmodial activity and toxicity of extracts of plants used in traditional malaria therapy in Meru and Kilifi districts of Kenya. J. Ethnopharmacol. 106, 403-407.

Koch, A., Tamez, P., Pezzuto, J., and Soejarto, D. (2005). Evaluation of plants used for antimalarial treatment by the Maasai of Kenya. J. Ethnopharmacol. 101, 95-99. 
Kokwaro, J. O. (1993). Medicinal Plants of East Africa. Nairobi: East Africa Literature Bureau.

Kristina, J. S. (2002). Herbal remedies traditionally used against malaria in Ghana: bioassay guided fractionation of Microglossa pyrifolia (Asteraceae). Z. Naturforsch. C 57, 1022-1027.

Kumar, S., Epstein, J. E., Richie, T. L., Nkrumah, F. K., Soisson, L., Carucci, D. J., and Hoffman, S. L. (2002). Role of natural products in modern medicine. Trends Parasitol. 18, 129.

Kuria, K. A. M., Muriuki, G., Masengo, W., Kibwage, I., Hoogmartens, J., and Leekeman, G. M. (2001). Antimalarial activity of Ajuga remota Benth (Labiatae) and Caesalpinia volkensii Harms (Caesalpinaceae): in vitro confirmation of ethnopharmacological use. J. Ethnopharmacol. 74, 141-148.

Manandhar, N. P. (1993). Herbal remedies of Surkhet district, Nepal. Fitoterapia 64, 266-272.

Manguro, L. O. A., Ugi, I., Hermann, R., and Lemmen, P. (2003). Flavonal and drimane-type sesquiterpene glycosides of Warburgia stuhlmannii leaves. Phytochemistry 63, 497-502.

Maregesi, S., Van Miert, S., Pannecougue, C., Feiz Haddad, M. H., Hermans, N., Wright, C. W., Vlientick, A. J., Apers, A. S., and Pieters, A. S. (2010). Screening of Tanzanian medicinal plants against Plasmodium falciparum and human immunodeficiency virus. Planta Med. 76, 195-201.

Meyer. (2002). Two novel assays for the detection of haemin-binding properties of antimalarials evaluated with compounds isolated from medicinal plants. J. Antimicrob. Chemother. 50, 25-31.

Moshi, M. J., Godeliver, A. B. K., and Zakaria, H. M. (2005). Plants used to treat epilepsy by Tanzanian traditional healers. J. Ethnopharmacol. 97, 327-336.

Mouchet, J. (1999). Vectors and environmental factors in malaria. Transfus. Clin. Biol. 6, 35-43.

Mugabe, J. Clark, N. (eds). (1998). Managing Biodiversity: The National systems of Conservation and Innovation in Africa. Nairobi: Acts Press.

Muthaura, C. N., Keriko, J. M., Derese, S., Yenesew, A., and Rukunga, G. M. (2011). Investigation of some medicinal plants traditionally used for treatment of malaria in Kenta as potential sources of antimalarial drugs. Exp. Parasitol. 127, 609-629.

Muthaura, C. N., Rukunga, G. M., Chhabra, S. C., Mungai, G. M., and
Njagi, E. N. M. (2007). Traditional antimalarial phytotherapy remedies used by the Kwale community of the Kenyan Coast. J. Ethnopharmacol. $114,377-386$.

Neuwinger, H. D. (1994). African Ethnobotany: Poisons and Drugs: Chemistry, Pharmacology, Toxicology. London, NY: Chapman \& Hall.

Neuwinger, H. D. (2000). African Traditional Medicine: A Dictionary of Plant Use and Applications. Stuttgart: Medpharm Scientific Publishers, 589.

Nguta, J. M., Mbaria, J. M., Gakuya, D. W., Gathumbi, P. K., and Kiama, S. G. (2010a). Antimalarial herbal remedies of Msambweni, Kenya. $J$. Ethnopharmacol. 128, 424-432.

Nguta, J. M., Mbaria, J. M., Gakuya, G. W., Gathumbi, P. K., and Kiama, S. G. (2010b). Traditional antimalarial phytotherapy remedies used by the South Coast community, Kenya. J. Ethnopharmacol. 131, 256-267.

Njoroge, G. N., and Bussmann, R. W. (2006). Diversity and utilization of antimalarial ethnophytotherapeutic remedies among the Kikuyus (Central Kenya). J. Ethnobiol. Ethnomed. 2,8 .

Nkunya, M. H. H., Jonker, S. A., De Gelder, R., Wachira, S. W., and Kilampa, C. (2004). (DL)-schefflone: a trimeric monoterpenoid from the root bark of Uvaria scheffleri. Phytochemistry 65, 399-404.

Nkunya, M. H. H., Weenen, H., Bray, D. H., Magani, Q. A., and Mwasumbi, L. B. (1991). Antimalarial activity of Tanzanian plants and their active constituents. The genus Uvaria. Planta Med. 57, 341-343.

Nuwaha, F. (2002). People's perception of malaria in Mbarara, Uganda. Trop. Med. Int. Health 7, 462-470.

Nyasse, B., Nono, J., Sonke, B., Deniel, C., and Fontaine, C. (2004). Trypanocidal activity of bergenin, the major constituent of Flueggea virosa, on Trypanosoma brucei. Pharmazie $59,492-494$.

Oketch-rabah, H. A., Dossaji, J. F., and Mberu, E. K. (1999). Antimalarial activity of some Kenyan medicinal plants. Pharm. Biol. 37, 329-334.

Omulokoli, E., Khan, B., and Chhabra, S. C. (1997). Antiplasmodial activity of four Kenyan medicinal plants. J. Ethnopharmacol. 56, 133-137.

Raghunathaiyar, S. (1996). Indian Medicinal Plants, Vol. 3. Hyderabad: Orient Longman, 104-105.

Rasoanaivo, P., Ratsimamanga-Uverg, S., Ramanitrahasimbola, D., Rafatro, H., and Rakoto-Ratsimamanga, A. (1999). Screening of plant extracts from Madagascar for research on antimalarial activity and potentiating effect of chloroquine. $J$. Ethnopharmacol. 64, 117-126.

Reed, J. D. (1986). Relationship among soluble phenolics, insoluble proanthocyanidins and fiber in East African rowse species. J. Range Manag. 39, 5-7.

Reynolds, F. L. S. (2008). Comparative chromatographic patterns of leaf exudates components from shrubby aloes. Bot. J. Linn. Soc. 102, 273-285.

Ridley, R. G. (1997). Plasmodium: drug discovery and development an industrial perspective. Exp. Parasitol. 87, 293-304.

Rodgers, C. B., and Coombes, P. H. (1999). Acidic triterpene glycosides in trachoma secretions differentiate subspecies of Combretum collinum in South Africa. J. Nat. Prod. 27, 321-323.

Runyoro, D. K. B., Ngassapa, O. D., Matea, M. I. N., Joseph, C. C. and Moshi, M. J. (2006). Medicinal plants used by Tanzanian traditional healers in the management of Candida infections. J. Ethnopharmacol. 106, 158-165.

Sfikas, G. (1980). Heilpflanzen Griechenlands. Athen: P. Efstathiadis and Sohne AG.

Sharma, J. D., and Sharma, P. (2001). Assessing African medicinal plants for efficacy and safety. Phytother. Res. $15,1$.

Smolenski, S. J., Silinis, H., and Farnsworth, N. R. (1975). Alkaloid screening. VIII. Lloydia 386 , 497-528.

Snow, R. W., Guerra, C. A., Noor, A. M., Myint, H. Y., and Hay, S. I. (2005). Nature 434, 214.

Sofowora, A. (1993). Medicinal Plants and Traditional Medicine in Africa. Chichester: John Wiley and Sons Ltd., 177.

Tabuti, J. R. S. (2008). Herbal medicines used in the treatment of malaria in Budiope County, Uganda. J. Ethnopharmacol. 116, 33-42.

Tan, P. V. (1997). Plants used as antimalarials. Phytother. Res. 11, 45-47.

Taniguchi, M., Chapya, A., Kubo, I., and Nakanishi, K. (1978). Screening of East African plants for antimalarial activity. Chem. Pharm. Bull. 26 2910-2913.

Tona, L. (1999). Antimalarial activity of twenty crude extracts from nine African medicinal plants used in Kinshasa, Congo. J. Ethnopharmacol. 68, 193-203.

Tona, L., Cimanga, R. K., Mesia, K., Musuamba, C. T., De Bruyne,
T., Apers, S., Hernans, N., Van Miert, S., Pieters, L., Totte, J., and Vlietinck, A. J. (2004). In vitro antiplasmodial activity of extracts and fractions from seven medicinal plants used in the Democratic Republic of Congo. J. Ethnopharmacol. 93, 27-32.

Tona, L., Kambu, K., Ngimbi, N., Cimanga, K., and Vlietinck, A. J. (1998). Antimoebic and phytochemical screening of some Congolese medicinal plants. $J$. Ethnopharmacol. 61, 57-65.

Tor-anyiin, T. A., Sha'ato, R., and Oluma, H. O. A. (2003). Ethnobotanical survey of antimalarial medicinal plants among the Tiv. people of Nigeria. J. Herbs Spices Med. Plants 10, 61-74.

Trape, J. F. (2002). Combating malaria in Africa. Trends Parasitol. 18, 224-230.

Tshibangu, J. N., Wright, A. D., and Konig, G. M. (2003). HPLC isolation of the antiplasmodially active benzylisoquinone alkaloids present in roots of Cissampelos mucronata. Phytochem. Anal. 14, 13-22.

Van Wyk, B. E., Van Oudtshoorn, B., and Gericke, N. (2002). Medicinal Plants of South Africa. Pretoria: Briza Publications.

Van Wyk, B. E., and Wink, M. (2004). Medicinal Plants of The World: An Illustrated Scientific Guide to Important Medicinal Plants and Their Uses. Portland, OR: Timber Press, 480.

Waako, P. J., Gumede, B., Smith, P., and Folb, P. L. (2005). The in vitro and in vivo antimalarial activity of Cardiospermum halicacabum L. and Momordica foetida Schumch. Et Thonn. J. Ethnopharmacol. 99, 137-143.

Wall. (2006). Steroidal sapogenins XLIII. Survey of plants for steroidal sapogenins and other constituents. J. Am. Pharm. Assoc. 46, 653-684.

Wanyoike, G. N., Chhabra, S. C., Langa'nt-Thoruwa, C. C., and Omar, S. A. (2004). Brine shrimp toxicity and antiplasmodial activity of five Kenyan medicinal plants. J. Ethnopharmacol. 90, 129-133.

Watt, J. M., and Breyer-Brandwijk, M. G. (1962). The medicinal and poisonous plants of Southern and Eastern Africa, 2nd Edn. London: E. \& S. Livingstone Ltd.

Weenen, H., Nkunya, M. H. H. Bray, D. H., Mwasubi, L. B., Kinabo, L. S., and Kilimali, V. A. (1990) 
Antimalarial activity of Tanzanian medicinal plants. Planta Med. 56, 368-370.

Williamson, J. (1975). Useful plants of Malawi, Rev. Edn. University of Malawi, Zomba.

Wondimu, A., Dagne E., and Waterman P. G. (1998). Quinoline alkaloids from the leaves of Teclea simplicifolia. Phytother. Res. 27, 959-960.

World Health Organization. (1996). WHO Weekly Epidemiological Record, Geneva 71, 17-24.
World Health Organization. (2000). General Guidelines for Methodologies on Research and Evaluation of Traditional Medicine. Geneva: WHO/EDM/TRM/2000.1.

World Health Organization. (2005). Roll Back Malaria. Working Document, Geneva.

Conflict of Interest Statement: The authors declare that the research was conducted in the absence of any commercial or financial relationships that could be construed as a potential conflict of interest.

Received: 22 February 2011; accepted: 06 June 2011; published online: 24 June 2011.

Citation: Nguta JM, Mbaria JM, Gathumbi PK, Gakuya D, Kabasa JD and Kiama SG (2011) Ethnodiagnostic skills of the Digo community for malaria: a lead to traditional bioprospecting. Front. Pharmacol. 2:30. doi: 10.3389/fphar.2011.00030

This article was submitted to Frontiers in Ethnopharmacology, a specialty of Frontiers in Pharmacology.

Copyright (C) 2011 Nguta, Mbaria, Gathumbi, Gakuya, Kabasa and Kiama. This is an open-access article subject to a nonexclusive license between the authors and Frontiers Media SA, which permits use, distribution and reproduction in other forums, provided the original authors and source are credited and other Frontiers conditions are complied with. 